\title{
Investigation on Newcastle Disease Virus (NDV), Infectious Bursal Disease Virus (IBDV) and Avian Poxvirus (APV) In Magellanic Penguins in Southern Region of Brazil
}

\author{
Cristina Freitas Nunes ${ }^{1}$, Fabiane Fonseca ${ }^{1,3}$, Alice Teixeira Meirelles Leite ${ }^{2}$, Rodolfo Pinho \\ da Silva Filho ${ }^{2}$, Paula Fonseca Finger ${ }^{1}$, Clarissa Caetano Castro ${ }^{1}$, Geferson Fischer ${ }^{1}$, \\ Gilberto D'avila Vargas ${ }^{1}$ and Silvia de Oliveira Hübner ${ }^{1 *}$ \\ ${ }^{1}$ Laboratorio de Virologia e Imunologia; Faculdade de Veterinária; Universidade Federal de Pelotas; ${ }^{2}$ Centro de \\ Reabilitação de Fauna Silvestre e Marinha; Faculdade de Veterinária; Universidade Federal do Rio Grande; \\ ${ }^{3}$ Centro de Recuperação de Animais Marinhos; Museu Oceanográfico Prof. Eliézer de C. Rios; Universidade \\ Federal do Rio Grande; Rio Grande - RS - Brasil
}

\begin{abstract}
To investigate the exposure of the Newcastle disease virus (NDV), infectious bursal disease virus (IBDV) and avian poxvirus (APV) in Magellanic penguins found on the beaches in Southern regions of Brazil, the frequency of serum antibodies was estimated in 89 samples taken during 2005 and 2006. All the penguins were negative for the presence of antibodies against NDV by hemagglutination inhibition test and to APV by indirect ELISA. The reactivity was similar to the positives controls using ELISA kit for the IBDV made in the chickens in 50 samples. This reactivity also was demonstrated in 42 samples using agar gel immunodiffusion. No clinical signs related to IBDV infection were observed. The results indicated the absence of infection by NDV and APV but suggested IBDV exposure in the population of penguins studied.
\end{abstract}

Key-words: magellanic penguins, antibodies, Newcastle disease virus, Infectious bursal disease virus, Avian poxvirus

\section{INTRODUCTION}

Wild birds may be susceptible to many pathogens common to domestic animals and humans. This aspect leads to a growing concern about the diseases that affect them. Accordingly, some investigators have reported evidence of viral infections on several species of penguins that live in the Antarctic and sub-Antarctic areas (Morgan et al. 1980; Alexander et al. 1989; Austin et al. 1993; Jackwood, 2005). Due to an increase in the proximity of humans to penguins, there is concern about introducing avian virus to their colonies, which could contribute together with man predatory action to the incidence of high levels of mortality of these birds (Morgan et al. 1985; Gardner et al. 1997). On the other hand, migratory birds, including penguins, due to their biological characteristics can disseminate pathogen microorganisms, acting as biological or mechanical carriers, or as the host of the virus, becoming important vectors of viral diseases (Murphy et al. 1999).

Magellanic penguins (Spheniscus magellanicus) are birds that live in the South American coast, in the Patagonian shore, South of Argentina. In the

*Author for correspondence: sohubner@yahoo.com.br 
winter, they move to the Southern Brazil following the cold currents from Malvinas (Willians 1995), which meet the hot currents in the South region of Brazil (Rio Grande do Sul state), where the currents lose their strength. During this period, many penguins are found in the beaches and are usually weak (Ruoppolo et al. 1999). They are then taken to specialized rehabilitation centers before being returned to the sea. There it is possible to investigate the agents that infect them.

Although some infections can be of concern to wildlife (Hübner et al. 2010), data regarding the pathogens infecting the penguins are rare. The understanding about the viral infections of penguins is highly important for the establishment of monitoring programs. This work was carried out aiming at detecting the evidences of infections of penguins found in the South of Brazil, caused by the viruses that commonly affect poultry. In this context, the presence of antibodies to the Newcastle disease virus (NDV), infectious bursal disease virus (IBDV) and avian poxvirus (APV) was investigated.

\section{MATERIAL AND METHODS}

\section{Animals and samples}

Magellanic penguins analyzed in the present study were found on the beaches in the Southern and Central regions of Rio Grande do Sul state coast in Brazil from August 2005 to December 2006. The animals were taken to two centers responsible for receiving, rehabilitation and re-establishment of these penguins: Centro de Recuperação de Animais Marinhos (CRAM) from Universidade Federal do Rio Grande (FURG), and the Centro de Estudos Costeiros, Limnológicos e Marinhos (CECLIMAR), from Universidade Federal do Rio Grande do Sul (UFRGS). Usually, the birds arrived were weak. After recovering their body conditions, serum from all the Magellanic penguins rescued during the study period (89 samples) were collected and taken to the laboratory. All the birds were identified with a ring and had their blood collected from the medial metatarsal vein using $25 \times 7$ needle (license number 047/2005/RS- IBAMA). The serum obtained after the centrifugation $(400 \mathrm{x} \mathrm{g})$ was identified and stored at $-20{ }^{\circ} \mathrm{C}$ until testing for specific antibodies.

\section{Hemagglutination inhibition test to NDV}

Penguins can develop antibodies inhibitors of hemagglutination to NDV (Morgan et al. 1985). Sera were submitted to hemagglutination inhibition test (HI) as described by OIE (2010) in microplates with a "V" bottom. Serum serial dilutions from 1:2 to 1:512 in phosphate buffered saline (PBS), $\mathrm{pH} 7.2$, were incubated with NDV (strain La Sota -4 haemagglutination units) for 30 $\mathrm{min}$ at room temperature. After that a volume of $50 \mu \mathrm{l}$ of a chicken red blood cells suspension at $1 \%$ was added and the reading was made after about $40 \mathrm{~min}$ at room temperature. The HI titre was considered as the highest serum dilution completely inhibiting the viral hemagglutination. Positive serum from chicken immunized was used as control. Back titration of antigen was included in all the tests to verify the number the hemagglutination units used.

\section{ELISA to IBDV}

Antibodies for IBDV were evaluated using the plates covered with antigen from IBDV (FlockChek® -Infectious Bursal Disease Antibody Test kit of the Idexx Laboratories). The serum samples were added at 1:500 dilution and after 30 minutes of the incubation and three washings, were incubated with the anti-chicken $\operatorname{IgY}$ peroxidase conjugate (Sigma Chemicals) for $1 \mathrm{~h}$ at $37{ }^{\circ} \mathrm{C}$. These anti-chicken $\mathrm{IgY}$ antibodies had cross-reactivity with $\operatorname{IgY}$ of penguin as demonstrated by ELISA (date not show) and Western blotting (Cray et al. 2008). The relative level of antibody was determined by calculating the sample to positive ratio $(\mathrm{S} / \mathrm{P})$. The $\mathrm{S} / \mathrm{P}$ ratio was obtained by dividing the mean OD value (S) of a given serum minus the mean negative control by the mean OD value $(\mathrm{P})$ of the positive control minus the mean of the negative control. The controls were provided in the kit. For the Idexx ELISA, sera were classified as positive when their $\mathrm{S} / \mathrm{P}$ value were equal or higher than 0.2 .

\section{Agar gel immunodiffusion (AGID) to IBDV}

Antigen (strain Luckert) and positive control antiserum were prepared as described by OIE (2010). Test sera were dispensed in four adjacent wells while the control positive sera were dispensed into the two remaining adjacent wells. Standardized IBDV antigen was placed in the central well. The plates were incubated at $37^{\circ} \mathrm{C}$ for 
$48 \mathrm{~h}$ in a humid chamber and lines of the identity were observed between the sera and the antigen. Results were taken as valid if the sera produced the line of identity.

\section{ELISA to APV}

The ELISA technique for APV was performed as described by Iritani and Sawaguchi (1994) with slight modifications. Chicken embryo fibroblasts (CEF) were multiplied in Eagle's minimal essential medium (E-MEM) supplemented with $10 \%$ foetal calf serum and enrofloxacin $(10 \mathrm{mg} / \mathrm{L})$. The supernatants of the CEF infected with Fowlpoxvirus (FWPV) mild strain, or mock infected cultures were harvested $48 \mathrm{~h}$ postinfection. The cells and supernatants were frozen at $-70{ }^{\circ} \mathrm{C}$ and clarified at $3000 \times \mathrm{g}$ for $20 \mathrm{~min}$ at $4^{\circ} \mathrm{C}$. Subsequently, the supernatants were centrifuged for $2 \mathrm{~h}$ at $70000 \times \mathrm{g}$ at $4{ }^{\circ} \mathrm{C}$. The pellets were re-suspended in Tris- $\mathrm{HCl} 1 \mathrm{mM}(\mathrm{pH}$ 7.2) at 1:200 the initial volume and used as positive and negative antigens for ELISA. The antigen was aliquoted and stored at $-70{ }^{\circ} \mathrm{C}$.

The variables parameters were optimized, which included antigen concentration, serum and secondary antibody dilutions as well as reduction of background noise by testing the control positive (immunized chickens) and negative sera (chickens Specific Pathogen Free). Microtitre plates were coated with $100 \mu \mathrm{l}$ per well of antigen diluted in carbonate buffer $\left(15 \mathrm{mM} \mathrm{Na} \mathrm{Na}_{2}, 35 \mathrm{mM}\right.$ $\mathrm{NaHCO}_{3}, \mathrm{pH} 9.5$ ) and incubated overnight at $4{ }^{\circ} \mathrm{C}$. The plates were washed three times in PBS containing $0.05 \%$ Tween 20 (PBS-T20), then treated with blocking solution (5\% bovine foetal serum in PBS-T20) for $60 \mathrm{~min}$ at $37{ }^{\circ} \mathrm{C}$ and washed three times with PBS-T20. Sera under test were diluted 1:50 in PBS-T20. After $1 \mathrm{~h}$ incubation at $37{ }^{\circ} \mathrm{C}$, the plates were washed three times with PBS-T20 and incubated with the antichicken IgY peroxidase conjugate (Sigma Chemicals) for $1 \mathrm{~h}$ at $37{ }^{\circ} \mathrm{C}$. After three further washings with PBST-20, $100 \mu \mathrm{L}$ of the substrate ortho-phenylenediamine (OPD; Sigma Chemicals) with $0.03 \% \mathrm{H}_{2} \mathrm{O}_{2}$ were added. The reaction was stopped by the addition of $\mathrm{H}_{2} \mathrm{SO}_{4}(2 \mathrm{M})$ after $5 \mathrm{~min}$ of incubation at room temperature. The optical density (OD) was determined at $492 \mathrm{~nm}$ using an ELISA Microplate Reader (Thermo Plate - TP reader). Each sample was tested in duplicate. The adjusted OD values of each sample were obtained by subtracting the absorbance of the mock antigen- coated well from that of the corresponding virus antigen-coated well.

\section{RESULTS AND DISCUSSION}

In the present study, 89 samples of Magellanic penguins were analyzed for the presence of antibodies to NDV, IBDV and APV viruses, aiming at finding the serological evidence of infection in the penguins that arrived in Southern region of Brazil. All the penguins showed negative results to the antibodies against NDV. This was similar to the results described in other studies for NDV with different species of penguins in Southern coast of Australia (Morgan et al. 1985), Antarctica (Morgan et al. 1988), Crozet archipelago of the Indic Ocean (Gauthier-Clere et al. 2002) and Galapagos Islands from Ecuador (Travis et al. 2006). However, the isolation of NDV from the penguins in the Antarctica (Alexander et al. 1989; Thomazelli et al. 2010) and the presence of NDV antibodies in the Adelie (Pygocelis adelie), Rockhopper (Eudyptes chrysocome schlegeli) and King penguins (Aptenodytes patagonica), in Macquaire island in sub Antarctica (Morgan and Westbury, 1981; Morgan et al. 1981) showed that these viruses infected the penguins in some areas. Besides, the isolation of the NDV in different wild birds species associated with the presence of anti-NDV antibodies in Megallanic penguins in Argentina also suggested the possibility of the interspecies transmission (Zanetti et al. 2005). It is known that penguins are susceptible to the pathogenic virus strains since the disease has occurred in captives Adelie penguins believed to have become infected in the wild (Pierson et al. 1975) and in a king penguin (Krauss et al. 1963). In chickens, respiratory, circulatory, gastrointestinal and nervous signs are seen; the particular set of clinical manifestations depends on the age and immune status of the host and on the virulence and tropism of the infecting strain (Murphy et al. 1999).

Regarding IBDV, using the Infectious Bursal Disease Antibody Test kit, $50(56.1 \%)$ of the samples from the penguins showed reactivity indicating the presumptive evidence of the presence of specific antibodies. Due to high number of penguins with antibodies, and considering that the commercial assay was 
optimized and validated for the chickens and not for the penguins, the agar gel diffusion test was also performed. By the AGID, the antibodies were detected in 42 samples (47.2\%), confirming the reactivity observed by ELISA. These serological results suggested the IBDV exposure in the population of penguins studied. However, the significance of these finding could be uncertain. There was no clinical sign related to an IBDV infection. Perhaps there was cross reaction with the antibodies produced to other pathogens or these penguins were seropositive due to the exposure, presumably in Patagonia. The IBDV could naturally circulate in this area or, alternatively, there was an environmental contamination that could be associated with the increase in the number of people visiting South Polar Regions. The disease is highly contagious and the virus is difficult to chemically inactivate, therefore allowing it to be easily transmitted via contaminated clothing and equipment (Murrphy et al. 1999; Kerry et al. 1999). Penguins also have ample opportunity to become infected with these viruses by coming in contact with the contaminated foods such as poultry and poultry products (Kerry et al. 1999). Poultry meat has been linked to the transmission of Newcastle disease to other poultry. There is, therefore, a possibility that the transmission of this and other viral disease such as IBDV to Antarctic birds could occur through this route. There is a long history of feeding the kitchen scraps, including the poultry and eggs to skuas at Antarctic stations (Kerry et al. 1999). Perpetuation of infection among the members of the same species is probably accomplished by the direct transmission. The virus is relativity resistant in the environment and is highly infectious by the fecal-oral route (Murphy et al. 1999). Besides, migratory birds may be potent sources of infection (Ogawa et al. 1998; Jean et al. 2008; Kasanga et al. 2008), although this has not yet been related with the penguins. Several species of the birds, for example albatross and the giant petrel, can feed in the coastal waters of the continents to the north (Kerry et al. 1999). It is, therefore, possible that they in turn may also play a role in the transmission of IBDV into Magellanic penguins colonies.

Using virus neutralization test was possible demonstrated antibodies to IBDV in Adelie penguins from three sites close to the Mawson base (prevalence of antibodies of $1.5-2.6 \%$ ) in Antarctica (Gardner et al. 1997). Emperor penguins (Aptenodytes forsteri) studied from one site in this vicinity had seropositivity index similar to that found in this study (65.4\%). Adelie penguin samples from a remote location were negative in this study. Similarly, Galapagos penguins (Spheniscus mendiculus) from Ecuador and Humboldt penguins (Spheniscus humboldti) in Peru were seronegative (Travis et al. 2006; Smith et al. 2008). In other study, completed by a oneyear survey of the clinical signs of disease and serology, antibodies were detected in adult and chick king penguins and no clinical signs related to an IBDV were observed (Gauthier-Clere et al. 2002).

The presence of serum antibodies does not necessarily imply the presence of clinical disease. Although there are two distinct serotypes of the IBDV, only serotype 1 viruses cause disease in chickens. Serotype 2 viruses were originally isolated from the turkeys and studies demonstrated these isolates to be non-virulent for other nongallinaceous birds (Murphy et al. 1999; Ismail et al. 1988). IBDV isolated from the African Blackfooted (Sphenicus demersus) penguin and Macaroni penguins (Eudyptes chrysolophus) in a zoological park in the UK were classified as serotype 2 (Gough et al. 2002; Jackwood et al. 2005). The potential pathological effects of the IBDV serotype 1 or 2 on penguins are unknown. The ELISA and AGID tests do not detect the serotypic differences. In poultry, infection with the IBDV can result in clinical disease and high mortality or a prolonged immunosuppression, which has as consequence a greater susceptibility to other diseases due to the destruction of B cells and impaired humoral immune response in these birds (McFerran et al. 1980).

The exposure to poxvirus in Magellanic penguins was investigated by searching for the antibodies for the FWPV. Antibodies were not detected in any serum sample examined, suggesting the absence of exposure to the virus. Poxvirus infections of avian species are caused by the viruses of a single genus Avipoxvirus (APV) of the subfamily Chordopoxvirinae of the Poxviridae. Avian poxvirus has been reported in more than 60 species of wild birds (Tripathy et al. 1997). The outbreaks are commonly reported in other species of the birds and not in the penguins in the rehabilitation centers, due to proximity with domestic birds (Hansen et al. 1999). APV are antigenically and immunologically distinguishable from each other, but varying degrees of cross 
relationships do exist (Tripathy et al. 1973; Tripathy et al. 1997). In 1998, the isolation of the avian poxvirus from Jackass penguins (Spheniscus demercus) was reported (Stannard et al. 1998) from the lesions around the eyes. Studies confirmed that it was indeed a new species, denominated penguinpox virus (PPV) (Carulei et al. 2009).

To the best of our knowledge, this is the first report of investigation on the antibodies for virus in Magellanic penguins found on Brazilian beaches. Sera collected from 89 penguins showed the absence of antibody response to NDV and APV, indicating the absence of exposure to these viruses. However, there was evidence of the presence of antibodies for IBDV. At present, the significance of this pathogen to the overall health of the penguin populations is unknown. Further studies should be conducted in order to clarify this question about the IBDV on Magellanic penguins found on beaches in the Southern and Central regions of Rio Grande do Sul state coast. It is still important to ensure that the humans do not facilitate the introduction of these viruses into penguin population as it is uncertain what the outcome of such an introduction could be.

\section{REFERENCES}

Alexander DJ, Manvell RJ, Collins MS, Brockman SJ, Westbury HA, Morgan I, et al. Characterization of paramyxoviruses isolated from penguins in Antarctica and sub-Antarctica during 1976-1979. Arch Virol. 1989; 109 (1-2):135-143.

Austin FJ, Webster RG. Evidence of ortho- and paramyxoviruses in fauna from Antarctica. $J$ Wildl Dis. 1993; 29(4): 568-571.

Carulei O, Douglass N, Williamson AL. Phylogenetic analysis of three genes of Penguinpox virus corresponding to Vaccinia virus G8R (VLTF-1), A3L (P4b) and H3L reveals that it is most closely related to Turkeypox virus, Ostrichpox virus and Pigeonpox virus. Virol J. 2009; 6: 52.

Cray C, Villar D. Cross-reactivity of anti-chicken IgY antibody with immunoglobulins of exotic avian species. Vet Clin Pathol. 2008; 37(3): 328-331.

Gardner H, Brouwer S, Gleeson L, Kerry K, Riddle M. Poultry virus infection in Antarctic penguins. Nature. 1997; 387(6630): 245.
Gauthier-Clere M, Eterradossi N, Toquin D, Guittet M, Kuntz G, Maho Y. Serological survey of king penguin, Aptenodyptes patagonicus, in Crozet Archipelago for antibodies to infeccious bursal disease, influenza A and Newcastle disease viruses. Polar Biol. 2002; 25(4):316-319.

Gough RE, Drury SE, Welchman DB, Chitty JR, Summerhays GES. Isolation of Birnavirus and Reovirus-Like Agents from Penguins in the United Kingdom. Vet Rec. 2002; 151(14): 422-424.

Hansen W. Avian Pox. In: Friend M, Franson JC. Field manual of wildlife diseases: general field procedures and diseases of birds. Washington: USGS; 1999. p.63-170.

Hübner SO, Pappen FG, Ruas J, Vargas, GD, Fischer, $\mathrm{G}$, Vidor T. Antibodies against canine distemper virus (CDV), parvovirus (CPV) and coronavirus $(\mathrm{CCoV})$ in Pseudalopex gymmocercus (Graxaim-docampo) and Cerdocyon thous (Graxaim-do-mato) from the southern region of Brazil. Braz Arch Biol Technol. 2010; 53(3): 593-597.

Iritani Y, Sawaguchi K. Measurement of antibody titer to fowlpox virus by enzyme-linked immunosorbent assay. J Vet Med Sci. 1994; 56(6): 1191-1193.

Ismail NM, Saif YM, Moorhead PD. Lack of pathogenicity of five serotype 2 infectious bursal disease viruses in chickens. Avian Dis. 1988; 32(4): 757-759.

Jackwood DJ, Gough RE, Sommer, SE. Nucleotide and amino acid sequence analysis of a birnavirus isolated from penguins. Vet Rec. 2005; 156(17):550-552.

Kasanga CJ, Yamaguchi T, Wambura PN, Munang'andu HM, Ohya K, Fukushi H. Detection of infectious bursal disease virus (IBDV) genome in free-living pigeon and guinea fowl in Africa suggests involvement of wild birds in the epidemiology of IBDV. Virus Genes. 2008; 36(3): 521-529.

Kerry K, Riddle M, Clarke J. Diseases in Antarctic Wildlife. A report for The Scientific Committee on Antarctic Research (SCAR) and the Council of Managers of National Antarctic Programs (COMNAP). Australian Antarctic Division: Hobart; 1999.

Krauss H, Paulick C, Huchzermeyer F, Gylstorff I. Newcastle Disease in a king penguin. Dtsch Tierarztl Wochenschr. 1963; 70(11):307-309.

McFerran JB, Mcnulty MS, Mckillop ER. Isolation and serological studies with infectious bursal disease viruses from fowl, turkey and duck: demonstration of a second serotype. Avian Pathol.1980; 9(3):395-404.

Morgan IR, Westbury HA. Virological studies of Adelie penguins (Pygocelis adelie) in Antartica. Avian Dis. 1981; 25(4):1019-1026. 
Morgan IR, Westbury HA, Caple IW, Campbell J. A survey of virus infection in sub-antartic penguins on Macquaire Island, southern ocean. Aust Vet J. 1981; 57(7):333-334.

Morgan, I. R.; Westbury, H. A. and Campbell, J. Viral infections of little blue penguins (Eudyptula minor) along the southern coast of Australia. J Wildl Dis. 1985; 21(3):193-198.

Morgan IR, Westbury HA. Studies of viruses in penguins in the Vetsfold Hills. Hydrobiologia. 1988; 165(1): 263-269.

Murphy FA, Gibbs EPJ, Horzinek MC, Studdert MJ Veterinary Virology. 3nd ed. San Diego: Academic Press; 1999.

Ogawa M, Wakuda T, Yamaguchi T, Murata K, Setiyono A, Fukushi $\mathrm{H}$, et al. Seroprevalence of infectious bursal disease virus in free-living wild birds in Japan. J Vet Med Sci. 1998; 60(11):12771279.

OIE (2010). Manual of Diagnostic Tests and Vaccines for Terrestrial Animals. Paris: Office International des Epizooties. http://www.oie.int/internationalstandard-setting/terrestrial-manual/access-online/

Pierson GP, Pfow CJ. Newcastle Disease Surveillance in the United States. J Am Vet Med Assoc. 1975; 167(9): 801-803.

Ruoppolo V, Santos MCO. Aves e mamíferos marinhos visitantes da costa brasileira. Clínica Vet. 1999; 20: 37-40.

Smith KM, Karesh WB, Majluf P, Paredes R, Zavalaga $\mathrm{C}$, Reul AH, et al. Health evaluation of free-ranging Humboldt penguins (Spheniscus humboldti) in Peru. Avian Dis. 2008; 52(1): 130-155.
Stannard LM, Marais D, Kow D, Dumbell KR. Evidence for incomplete replication of a penguin poxvirus in cells of mammalian origin. J Gen Virol. 1998; 79(7):1637-1646.

Thomazelli LM, Araujo J, Oliveira DB, Sanfilippo L, Ferreira CS, Brentano L, et al. Newcastle disease virus in penguins from King George Island on the Antarctic region. Vet Microbiol. 2010; 146(1-2):155160.

Travis EK, Vargas FH, Merkel J, Gottdenker N, Miller RE, Parker PG. Hematology, serum chemistry, and serology of Galapagos penguins (Spheniscus mendiculus) in the Galápagos Islands, Ecuador. $J$ Wildl Dis. 2006; 42(3): 625-632.

Tripathy DN, Hanson LE, Killinger AH. Studies on differentiation of an Avian Pox Viruses. Avian Dis. 1973; 17(2): 325-333.

Tripathy DN, Reed WM. Pox. In: Calnek WB, Barnes HJ, Beard CW, Mcdougald LR, Saif YM, editor. Diseases of Poultry. 10. ed. Ames: Iowa State University Press, 997. p. 643-659.

Zanetti F, Berinstein A, Pereda A, Taboga O, Carrillo E. Molecular characterization and phylogenetic analysis of Newcastle disease virus isolates from healthy wild birds. Avian Dis. 2005; 49(4): 546-550.

Willians TD. The Penguins: Spheniscidae. New York: Oxford University Press; 1995.

Received: June 07, 2011; Revised: December 01, 2011; Accepted: May 15, 2012. 